\title{
Diversity and abundance of copepods on the north coast of Angola during hot season 2014-2016
}

\author{
Ivania Janilda da Silvae Castro ${ }^{1 凶}$, Paulo André de Sousa Coelho², \\ Elena A. Vanisova ${ }^{1}$ \\ ${ }^{1}$ Peoples' Friendship Russian University (RUDN University), \\ 8 Podolskoye Shosse, bldg 5, Moscow, 115093, Russian Federation \\ ${ }^{2}$ National Institute for Fisheries and Marine Research, \\ Murtala Mohamed Ave, Ilha de Luanda, Luanda, 2601, Republic of Angola
}

$\checkmark$ ivaniacastro@hotmail.com

\begin{abstract}
The present work is aimed at discovering the diversity and abundance of copepods in the zooplankton community on the north coast of Angola, during the hot season 2014-2016. The samples were collected during the research cruise on board the Norwegian research ship "Dr. Fridtjof Nansen" in February - March on the Congo River and Luanda monitoring lines. Zooplankton sampling was performed using a multinet net in an oblique trawl (2014) and a WP2 net in a vertical trawl (2015 and 2016), both with $180 \mu \mathrm{m}$ mesh. The samples were fixed in $4 \%$ formaldehyde and analyzed in the oceanography laboratory of the National Institute of Fisheries and Maritime Research in Angola. In the three years of sampling, copepods were present in the zooplankton community. The diversity of copepods on the northern Angolan coast, from 2014 to 2016 in the hot season, included 27 genera corresponding to 19 families. The Copepoda class was the most abundant group in the zooplankton community, corresponding to more than $80 \%$ of the abundance, having been represented by the orders Calanoida, Cyclopoida and Harpacticoida.
\end{abstract}

Keywords: zooplankton, north coast, Angola, copepods, zooplankton abundance, diversity

\section{Introduction}

Zooplankton corresponds to the set of heterotrophic planktonic organisms, belonging to several groups in the animal kingdom, thus comprising an immensity of organisms of different shapes and dimensions, uni- and multicellular [1]. In general, zooplankton occupies a key position in the aquatic food chain, as it is responsible for secondary productivity and for the transport and regeneration of nutrients through its high metabolism [2; 3]. The main zooplanktonic groups include ciliates, cnidarians, ctenophores, pteropods, crustaceans, pelagic tunicates (salps, doliolids, appendicularians), chaetognaths and fish larvae [3; 4].

Crustaceans are generally the dominant group in zooplankton communities [3-5], and among them copepods predominate. Copepoda is the most abun- 
dant member of the marine plankton $[1 ; 6 ; 7]$, and consequently the dominant holoplanktonic form corresponding to about $90-97 \%$ of zooplanktonic biomass. Most copepods are marine, however, there are many freshwater species and others in soil water films. There are also many parasitic species of various marine and freshwater animals, particularly fish [8]. As most copepods feed on phytoplankton, they are the main link between phytoplankton and the upper trophic levels of the marine food chain and an important part of the diet of many marine animals is composed of copepods [8; 9].

Knowing the diversity of copepods in zooplankton communities is relevant due to the ecological importance of copepods, added to the fact that they are identified as the most abundant components of zooplankton. The northern region of the Angolan coast is one of the two zones of high zooplankton concentration in Angolan sea waters [10], and our study on the diversity of the Copepoda class serves to complement this information.

The main purpose of the work was to study the composition of copepods within the zooplankton community on the north coast of Angola during the hot season (February - March) 2014-2016. The following specific objectives were defined: to describe the diversity of copepods in the zooplankton community and to determine dominance of orders; determine the abundance of copepods in the zooplankton community during the study period.

\section{Materials and methods}

The study area corresponds to the northern part of the Angolan coast ( $\left.5^{\circ} \mathrm{S}-9^{\circ} \mathrm{S}\right)$ and includes the Congo River Monitoring Line (RCML) and the Luanda Monitoring Line (LDML) (Figure 1). The zooplankton samples were collected during the cruises exploring the marine resources of Angola, on board the Norwegian research ship "Dr. Fridtjof Nansen", in the 3 periods of the hot season: February 3 to March 5, 2014; February 14 to March 23, 2015; February 25 to March 26, 2016.

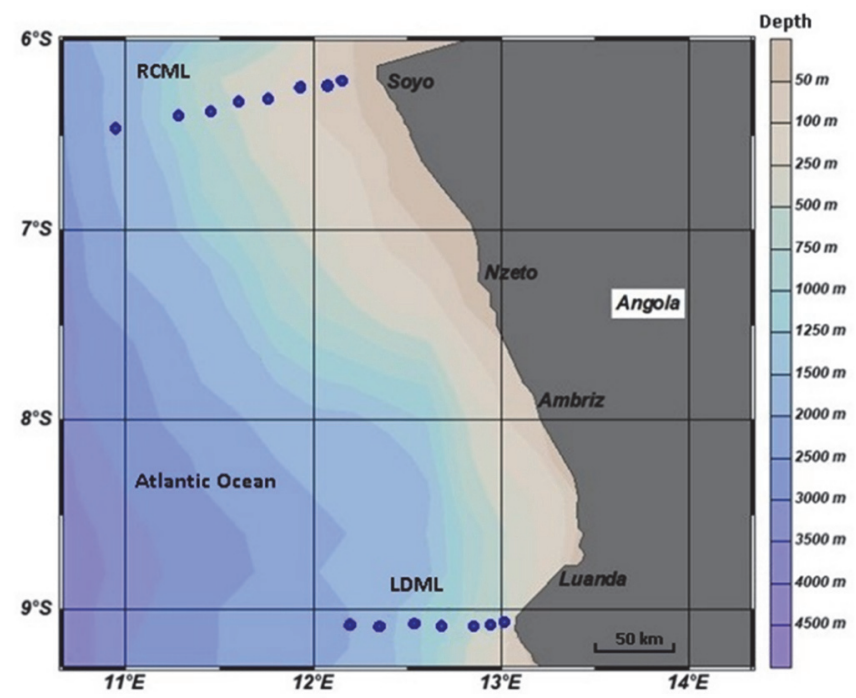

Figure 1. Study area - northern coast of Angola. The dots indicate the sampling locations (stations): $\mathrm{RCML}$ - Congo river monitoring line; LDML - Luanda monitoring line

Source: data of the National Institute for Fisheries and Marine Research. 
In each monitoring line the stations were approximately $10-30 \mathrm{~km}$ apart. Zooplankton sampling was performed using a multinet net in an oblique trawl (2014) and a WP2 net in a vertical trawl (2015 and 2016), both with $180 \mu \mathrm{m}$ mesh. The multinet contains 5 nets, and the samples were collected at five depth intervals $(0-25,25-50,50-75,75-100$ and 100-200 m), in contrast, WP2 corresponds to a unique type of network sampling. In all, 83 samples were collected (Table 1).

Sample analysis included laboratory processing according to accepted methods [6], and quantitative and qualitative data analysis. Abundance (No. org. $/ \mathrm{m}^{3}$ ) was calculated using the formula [11]: $N=n / v$, where $n$ - number of organisms from each taxon in the sample, and $v$ - volume of filtered water during drag. Dominance was calculated according to the formula [12]: $\mathrm{Ar}=\mathrm{N} \times 100 \% / \mathrm{Na}$, where $N$ - number of organisms from each taxon in the sample, and $\mathrm{Na}$ - sum of the total number of organisms in the sample. The zooplankton biomass was determined using the gravimetric method of fresh weight [13].

Table 1

Number of stations and samples collected in the northern part of the Angolan coast during the hot season, 2014-2016

\begin{tabular}{|c|c|c|c|c|c|c|}
\hline \multirow{2}{*}{ Line } & \multicolumn{2}{|c|}{2014} & \multicolumn{2}{|c|}{2015} & \multicolumn{2}{|c|}{2016} \\
\hline & Stations & Samples & Stations & Samples & Stations & Samples \\
\hline RCML & 8 & 30 & 6 & 6 & 7 & 11 \\
\hline LDML & 7 & 23 & 7 & 7 & 6 & 6 \\
\hline Total & 15 & 53 & 13 & 13 & 13 & 17 \\
\hline
\end{tabular}

\section{Results and discussion}

Below, the diversity of copepods (systematic classification) of the zooplankton community in the period under study, according to Boltovskoy [7], and Ruppert and Barnes [8], as well as the analysis of the dominance of orders are represented. None of the registered organisms have been identified to their species. The symbols indicate the year in which the organization was registered, respectively: $*-2014 ; \bullet-2015 ;-2016$.

Kingdom: Animalia Linnaeus, 1758

Phylum: Arthropoda

Subphylum: Crustacea

Class: Copepoda

Order: Calanoida Sars, 1903

Family: Calanidae Dana, 1849

Genus: Calanoides $* \bullet$

Genus: Calanus

Genus: Nannocalanus *

Family: Paracalanidae Giesbrecht, 1892

Genus: Paracalanus

Genus: Calocalanus

Family: Eucalanidae Giesbrecht, 1892

Genus: Eucalanus *

Genus: Pareucalanus 
Genus: Rhincalanus $* \bullet \bullet$
Genus: Subeucalanus $* \bullet \bullet$

Family: Clausocalanidae Giesbrecht, 1892

Genus: Clausocalanus

Family: Aetideidae Giesbrecht, 1892

Genus: Aetideus

Family: Euchaetidae Giesbrecht, 1892

Genus: Euchaeta

Genus: Paraeuchaeta $\bullet$

Family: Augaptilidae Sars, 1905

Genus: Haloptilus

Family: Metridinidae Sars, 1902

Genus: Metridia $* \bullet \bullet$

Genus: Pleuromamma

Family: Centropagidae Giesbrecht, 1892

Genus: Centropages

Family: Temoridae Giesbrecht, 1892

Genus: Temora

Family: Candaciidae Giesbrecht, 1892

Genus: Candacia

Family: Pontellidae Dana, 1953

Genus: Labidocera *

Family: Lucicutiidae Sars, 1902

Genus: Lucicutia

Family: Acartiidae Sars, 1903

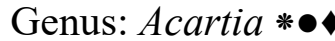

Family: Scolecitrichidae

Genus: Scolecithrix

Order: Cyclopoida Burmeister, 1834

Family: Oithonidae Dana, 1853

Genus: Oithona Baird, 1843

Family: Oncaeidae Giesbrecht, 1892

Genus: Oncaea

Family: Sapphirinidae Thorell, 1859

Genus: Sapphirina *

Family: Corycaeidae Dana, 1852

Genus: Corycaeus Dana, $1846 * \bullet$

Order: Harpacticoida Sars, 1903

The diversity of copepods included 27 genera corresponding to 19 families. Regarding the abundance, in three years sampling, both in the Congo monitoring line and in the Luanda line, copepods were the most abundant organisms, corresponding to more than $80 \%$ of the zooplankton community's abundance. Table 2 indicates the abundance of copepods within the zooplankton community in the period under study.

The results obtained by us agree with the previously described results by several authors about the great abundance of copepods in zooplanktonic sampling. 
Ruby [14], and André [15] obtained the same results in the study area of Angolan coast. The Copepoda class was represented by the orders: Calanoida, Cyclopoida and Harpacticoida. Figure 2 illustrates the dominance of Copepoda class orders in the 2014-2016 period. The "NI" category corresponds to the larval stages (copepodites and nauplii).

Copepods abundance (No. org. $/ \mathrm{m}^{3}$ ) in zooplankton community on the north Angolan coast, 2014-2016

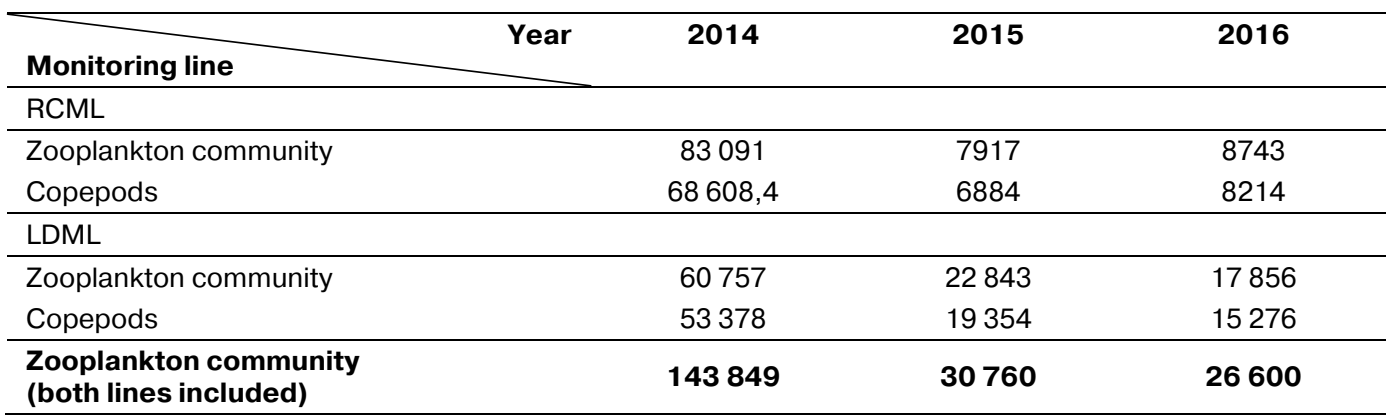

Source: data of the National Institute for Fisheries and Marine Research.

The order Calanoida was the dominant order on the north coast of Angola in the period 2015-2016. The order includes the genera Calanus (genus dominant on the Congo line in 2015 and Luanda line in 2016) and Calanoides (dominant genus on the Luanda line in 2015). Free-living and predominantly planktonic copepods [8], the order is the most successful of Copepoda's orders. Its success is due to the colonization of the entire pelagic environment, both in marine and freshwater ecosystems and saline lagoons [16]. They are rarely found in associations with other animals. Many species consume phytoplankton, others, predators, feed on a wide variety of prey [17].

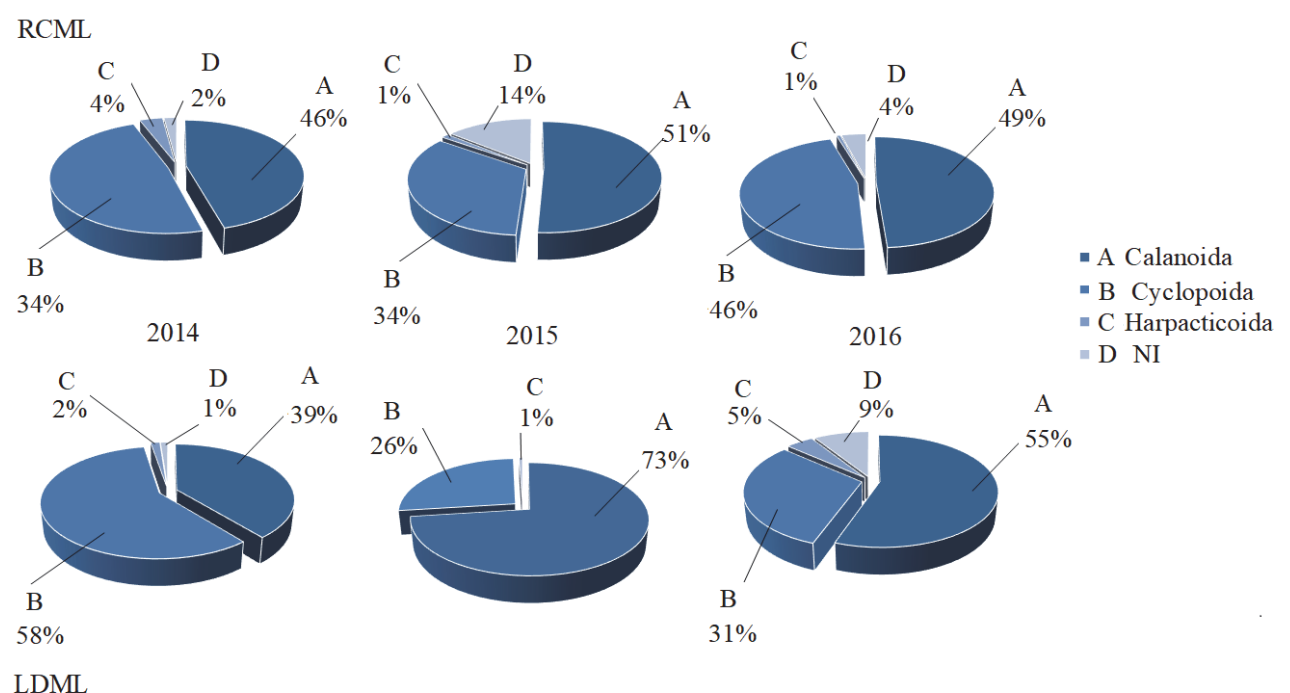

Figure 2. Dominance of orders in Copepoda class on the north coast of Angola, 2014-2016 Source: data of the National Institute for Fisheries and Marine Research. 
The order Cyclopoida was the second in terms of dominance. The order has planktonic and benthic, marine, and freshwater representatives. It includes some parasites [8]. Cyclopoida is the most abundant and successful order among copepods in freshwater ecosystems [17]. The Oncaeidae family is considered one of the most abundant in oceanic communities [17]. The genus Oncaea (dominant genus in 2014 in both monitoring lines and in the Congo river line in 2016) belongs to this order.

The order Harpacticoida had a low representativeness in the study area. Mainly constituted by benthic or epibentonic organisms with a pelagic minority $[8 ; 9 ; 17]$, harpaticoides are adapted to marine, freshwater, and even semi-terrestrial habitats such as wet plants and decomposing leaves [18].

\section{Conclusion}

As previously described about the zooplankton community, the largest percentage of zooplankton abundance is attributed to copepods. In the northern part of the Angolan coast, Copepoda class was represented by the orders Calanoida, Cyclopoida and Harpacticoida.

\section{References}

[1] Ré P. (ed.). Ecologia-Marinha (Sebenta). Lisboa, Portugal; 2005.

[2] Bradford-Grieve J, Hugget J. Guide to some common copepods in the Benguela current LME. Zooplankton Workshop, January 2007. Swakopmund, Namibia; 2007.

[3] Harris RP, Wiebe PH, Lenz J, et al. (ed.). ICES Zooplankton Methodology Manual. California, USA: Academic Press; 2000.

[4] Yoneda NF. (ed.). Plâncton. Paraná, Brasil: Centro de estudos do mar-Universidade Federal do Paraná; 1998.

[5] Raymond JEG. Plankton and productivity in the oceans. Vol. 2. Zooplankton. $2^{\text {nd }}$ ed. Oxford: Pergamon Press; 1983.

[6] Boltovskoy D. (ed.). Atlas del zooplancton en el Atlantico sudoccidental y metodos de trabajos con el zooplancton marinõ. Buenos Aires, Argentina: Mar del Plata-INIDE; 1981.

[7] Boltovskoy D. (ed.). South Atlantic zooplankton. Vols. 1, 2. Leiden, the Netherlands: Backhuys Publishers; 1999.

[8] Ruppert EE, Barnes RD. Zoologia dos Invertebrados. 6a edição. São Paulo, Brasil: Editora Rocca; 1996.

[9] Castellani C, Edwards M. (eds.). Marine Plankton: A practical guide to ecology, methodology, and taxonomy. Oxford: Oxford University Press; 2017.

[10] Da Silva AJ, Ruby C, Fernandes B. Revisão da investigação realizada na área do zooplâncton em águas marinhas de Angola. Luanda, Angola; 2005.

[11] Newell GH, Newell RC. Marine Plankton: a practical guide. London, Paris: Huchinson Educational Ltd; 1963.

[12] Lobo E, Leighton G. Estructura Comunitária de los Fitocenosis Planctonicos de los Sistemas de Desembocadura de Rios y Esteros de la Zona Central de Chile. Revista Biologia Marina - Valparaiso. 1986;22(1):1-29.

[13] Omori M, Ikeda T. Methods in marine zooplankton ecology. New York, USA: John Wiley \& Sons; 1984.

[14] Ruby CRPA. Influência da Dinâmica Sazonal da Frente Angola - Benguela Sobre a Comunidade Zooplanctônica ao largo da costa angolana em 2007 (dissertação). Luanda, Angola: Universidade Agostinho Neto; 2010. 
[15] André MCS. Análise da comunidade zooplanctônica da costa norte de Angola e sua relação com os parâmetros hidrográficos com ênfase ao redor do Rio Congo. Luanda, Angola: Universidade Agostinho Neto; 2011.

[16] Fosshagen A, Boxshall GA, Iliffe TM. The Epacteriscidae, a cave-living family of calanoid copepods. Sarsia. 2001;86:245-318.

[17] Huys R, Boxshall GA. Copepod Evolution. London, Paris: The Ray Society; 1991.

[18] Pesce GL. Introduction to copepods. Available from: http://www.luciopesce.net/copepods/ intro.htm (accessed: 03.02.2020).

Article history:

Received: 22.05 .2020

Revised: 15.06.2020

\title{
For citation:
}

Castro IJS, Coelho PAS, Vanisova EA. Diversity and abundance of copepods on the north coast of Angola during hot season 2014-2016. RUDN Journal of Ecology and Life Safety. 2020;28(3):285-292. http://dx.doi.org/10.22363/2313-2310-2020-28-3-285-292

\section{Bio notes:}

Ivania Janilda da Silvae Castro, master's student of the Department of System Ecology of the Faculty of Ecology of the Peoples' Friendship University of Russia (RUDN University). E-mail: ivaniacastro@hotmail.com

Paulo André de Sousa Coelho, Master in Sciences of the Sea and Coastal Zones, Head of the Department of Oceanography and Health of the Marine Ecosystem of the National Institute for Fisheries and Marine Research. E-mail: poolcoelho@gmail.com

Elena A. Vanisova, $\mathrm{PhD}$ in Biological Sciences, Associate Professor of the Department of System Ecology of the Faculty of Ecology of the Peoples' Friendship University of Russia (RUDN University). E-mail: vanhelen@mail.ru

\section{Разнообразие и численность копепод на северном побережье Анголы в жаркий сезон 2014-2016 гг.}

\author{
И.Ж.С. Кастро ${ }^{1 凶}$, П.А.С. Коэльо ${ }^{2}$, Е.А. Ванисова ${ }^{1}$ \\ ${ }^{1}$ Российский университет дружбы народов, \\ Российская Федерация, 115093, Москва, Подольское шоссе, д. 8, корп. 5 \\ ${ }^{2}$ Национального института рыбного хозяйства и морских исследований, \\ Республика Ангола, 2601, Луанда, Илья де Луанда, пр-кт Мурталь Мухаммеда \\ $\varangle$ ivaniacastro@hotmail.com
}

Аннотация. Обсуждается разнообразие и численность копепод в сообществе зоопланктона у северного побережья Анголы в жаркий сезон 2014-2016 гг. Образцы зоопланктона были собраны во время рейсов на борту норвежского исследовательского судна Dr. Fridtjof Nansen в феврале - марте на линиях мониторинга Луанды и реки Конго. 
Пробы зоопланктона отбирали с использованием мультисетевой системы - наклонный трал (2014) и сети WP2 - вертикальный трал $(2015,2016)$, обе с размером ячеи 180 мкм. Образцы закрепляли в 4\%-м формальдегиде и анализировали в океанографической лаборатории Национального института рыбного хозяйства и морских исследований (INIPM) в Анголе. Копеподы присутствовали в сообществе зоопланктона все три года исследований. Веслоногие ракообразные у северного побережья Анголы в жаркий сезон 2014-2016 гг. были представлены 27 родами, относящимися к 19 семействам. Класс Copepoda оказался самой многочисленной группой зоопланктона, составляя более $80 \%$ общей численности сообщества, и представлен тремя отрядами: Calanoida, Cyclopoida и Harpacticoida.

Ключевые слова: зоопланктон, северное побережье, Ангола, копеподы, численность зоопланктона, разнообразие

\section{История статьи:}

Дата поступления в редакцию: 22.05.2020

Дата принятия к печати: 15.06.2020

\section{Для цитирования:}

Castro I.J.S., Coelho P.A.S., Vanisova E.A. Diversity and abundance of copepods on the north coast of Angola during hot season 2014-2016 // Вестник Российского университета дружбы народов. Серия: Экология и безопасность жизнедеятельности. 2020. T. 28. № 3. C. 285-292. http://dx.doi.org/10.22363/2313-2310-2020-28-3-285-292

\section{Сведения об авторах:}

Кастро Иваниа Жанилда да Силвае, магистрант кафедры системной экологии экологического факультета Российского университета дружбы народов. E-mail: ivaniacastro@, hotmail.com

Коэльо Пауло Андре де Соуза, магистр наук о море и прибрежных зонах, заведующий отделом океанографии и здоровья морской экосистемы Национального института рыбного хозяйства и морских исследований. E-mail: poolcoelho@gmail.com

Ванисова Елена Александровна, кандидат биологических наук, доцент кафедры системной экологии экологического факультета Российского университета дружбы народов. E-mail: vanhelen@mail.ru 